Emilija Nikolić

Centar za nove tehnologije Viminacium d.o.o.

UDK 727.5:902(497.11)

Izvorni naučni članak

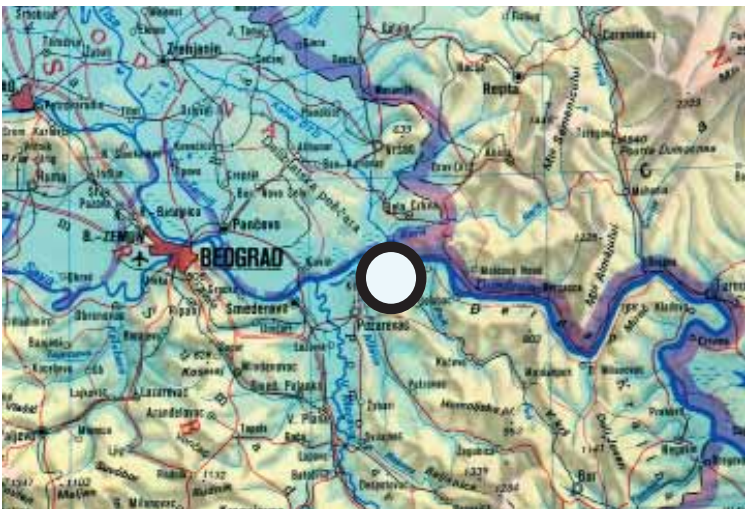

Viminacium, Stari Kostolac, Srbija

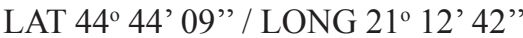

\title{
ARHEOLOŠKI NAUČNO-ISTRAŽIVAČKI CENTAR - DOMUS SCIENTIARUM VIMINACIUM
}

\begin{abstract}
APSTRAKT
Viminacijum je danas napoznatije i najposećenije arheološko nalazište u Srbiji.

Novoizgrađeni objekat Arheološkog naučno-istraživačkog centra "Domus Scientiarum Viminacium” "je pokušaj da se ispune zahtevi arhitekture i arheologije, teorije i prakse, etike i isplativosti...i svi drugi zahtevi koji se postavljaju pred proces projektovanja novih objekata građenih na arheološkim nalazištima.

U ovakvoj situaciji projektant postavlja samom sebi mnoga pitanja. Koji je pravi način na koji se projektuje dobra arhitektura? Postoji li opšta arhitektura koju možemo pratiti u svakom vremenu, ili postoje samo opšta arhitektonska pravila? Šta znači voditi savremen život u antičkom ambijentu? Možemo li zamisliti sebe u prošlosti ako smo prisutni u objektu koji ima odlike arhitekture prošlosti?

Da li je jedino prihvatljivo rešenje za projektovanje ovih objekata arhitektonska asocijacija na objekte prošlosti, ili su želje onih koji će biti korisnici objekta najvažniji tragovi koje projektant treba da prati ne bi li izneo konačan projekat ovakvog objekta?
\end{abstract}

Da li postoje odgovori na bilo koje od ovih pitanja?

KLJUČNE REČI: ANTIKA, ANTIČKI AMBIJENT, ARHEOLOGIJA, ARHITEKTURA, CENTAR, DOMINANTA, DOMUS, PODZEMNA ARHITEKTURA, TURIZAM, VIMINACIUM

"That which I have above insisted upon as the life of the whole, that spirit which is given only by the hand and eye of the workman, never can be recalled. Another spirit may be given by another time...".l

\section{John Ruskin}

1 Ruskin 1849, 179; Džon Raskin ovde, u poglavlju The Lamp Of Memory govori o restauraciji i konzervaciji objekata, ali je ova njegova teza bitna i za izgradnju današnjih objekata na osnovu objekata prošlosti i jedna je od tema ovog rada.

\section{UVOD}

Arheološko nalazište Viminacijum je dugo bilo mesto koje su posećivali samo arheolozi i lokalno stanovništvo. Arheolozi su obavljali težak i naporan posao istraživanja onoga što bi im kazalo nešto više o ovom rimskom gradu i vojnom logoru. Lokalno stanovništvo je takođe obavljalo težak i naporan posao, vršenje poljoprivrednih radova, i rad u industriji površinskog rudarskog kopa. 


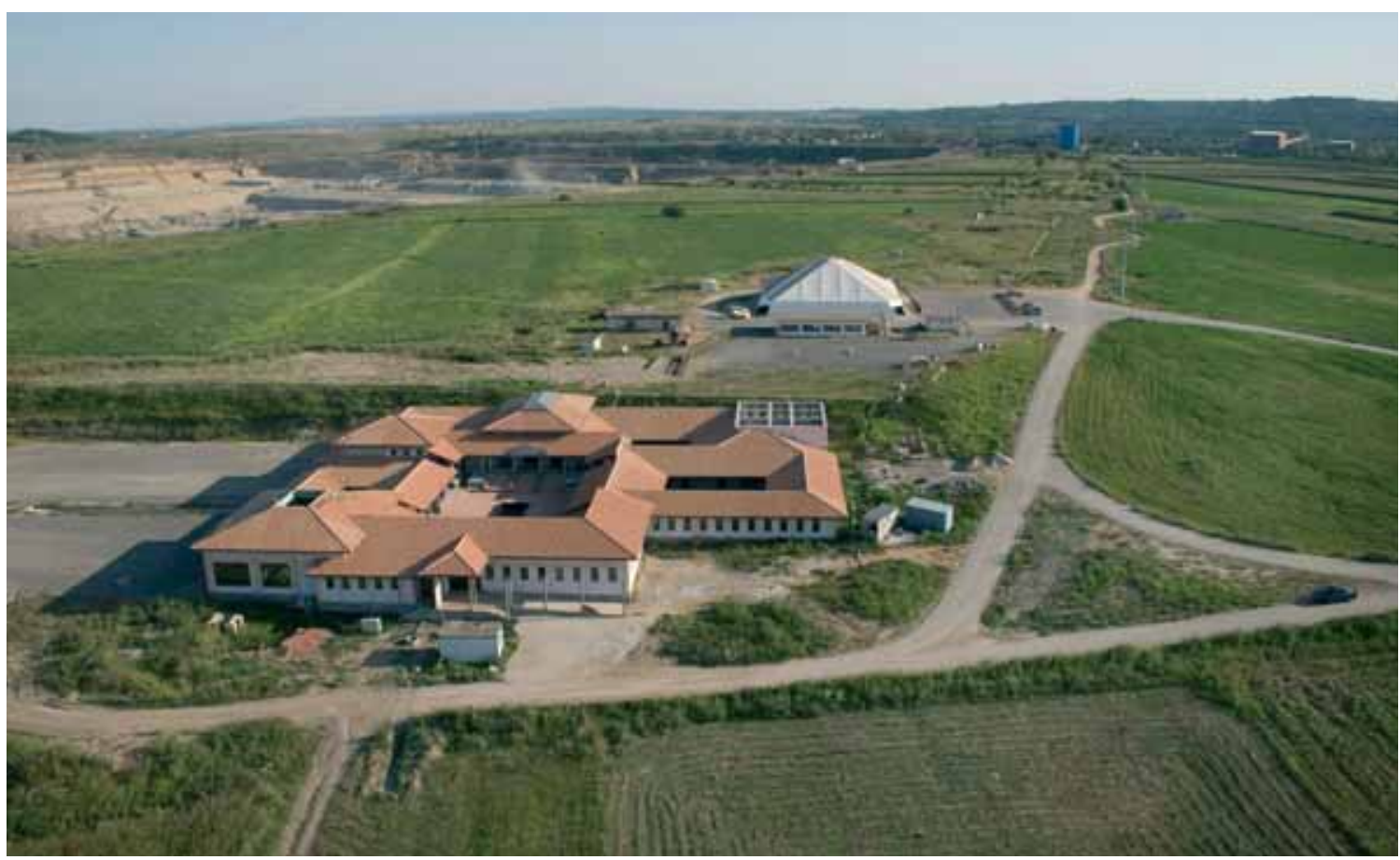

Objekat Arheološkog naučno-istraživačkog centra iz vazduha (snimio dr Miomir Korać)

Pre nekoliko godina, Viminacijum je dobio i nove posetioce - turiste. Iako su turisti nešto što se podrazumeva kada je u pitanju ovako značajno kulturno-istorijsko mesto, mnogo vremena je trebalo da prođe da bi se nešto promenilo na Viminacijumu i dovelo turiste na ovo mesto. Prve promene su podrazumevale osnovno ifrastrukturno uređenje samog lokaliteta, a onda se zbog sve većeg broja turista i njihovog interesovanja, osetila potreba za svim ostalim ugodnostima koje su turistima potrebne, da bi uživali, odmorili se i naučili nešto više iz istorije ovog mesta. Posle turista, arheolozi su takođe osetili potrebu da sve ono što cele godine tokom istraživanja pronađu, mogu na jednom mestu i da prouče i prezentuju, a $u$ isto vreme provedu svoje radno vreme $u$ prijatnom ambijentu. Lokalno stanovništvo je svoju korist u svemu što se desilo takođe pronašlo, i nekada njihove jedine delatnosti, poljoprivredu i rudarsku industriju, obogatio je turizam.

Domus Scientiarum Viminacium je posle pokrivanja istraženih arheoloških lokaliteta i izgradnje manjih uslužnih objekata, jedini novi objekat na ovom arheološkom nalazištu, koji polako obogaćuje turističku ponudu Viminacijuma i tako mu pomaže da postane ugledni primer drugim arheološkim nalazištima.

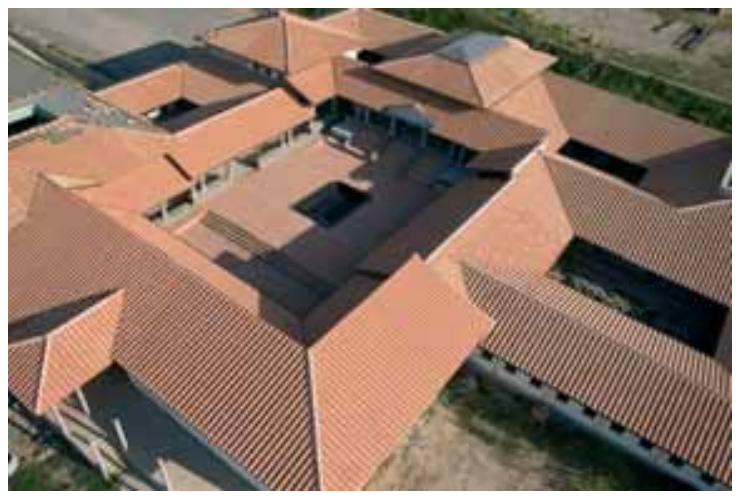

\section{POLOŽAJ DOMUSA - VIMINACIUM}

Viminacijum je bio najveći i najbogatiji rimski grad provincije Gornja Mezija, administrativni, vojni, trgovački i proizvodni centar. Danas ovaj rimski grad leži najvećim delom ispod zemlje, blizu ušća reke Mlave u reku Dunav, 12 kilometara udaljen od Požarevca, u Srbiji.

Ostaci Viminacijuma se prostiru preko kultivisanih, obradivih površina, pored termoelektrane "Drmno" i površinskog kopa. Preko 13.500 grobova je iskopano i istraženo na Viminacijumu, pa su ga neki nazvali i "gradom mrtvih". Najveći deo nadzemne arhitekture je uništen tokom vekova. Danas možemo samo šetati i razgledati taj mali deo preostale nadzemne arhitekture i njene temelje, i grobove - podzemnu arhitekturu Viminacijuma. 
Arheološki-naučno istraživački centar "Domus Scientiarum Viminacium" je projektovan u poljima Viminacijuma i postavljen na mesto gde će biti vidljiv sa dolazećeg puta koji vodi od ulaza u arheološki park do nekropole "Mauzolej", danas najposećenijeg mesta Viminacijuma i najbližeg suseda Domusa.

Ono što vidimo na Viminacijumu kada pogledamo oko sebe, osim termoelektrane i Domusa, su samo polja i tri pokrivena arheološka lokaliteta. Domus ima oblik koji je usklađen sa okruženjem i sa svojim dimenzijama izgleda kako da je uramljen u sliku povezanih polja oko njega. Na prostoru Viminacijuma gde nema mnogo vidljive antičke arhitekture, a gde je dominantna arhitektura objekat termoelektrane, trebalo je postaviti ovaj novi objekat, koji će tako imati konkurenciju u veličini, ali ne i u obliku ili bilo kojoj drugoj temi kuće. Ipak, nije se smelo dozvoliti da novi objekat postane najbitnija građevina na Viminacijumu i uzme značaj i malim ostacima rimske arhitekture.

\section{ARHITEKTURA I FUNKCIJA DOMUSA}

Arhitektura Domusa ima antičku kompoziciju u osnovi, i objekat orijentiše ka unutra, sa intimnim ambijentima pogodnim za rad i odmor posetilaca. Objekat predstavlja kompleks koji se sastoji od devet nadzemnih krila sa četiri mala atrijuma. Krila i mali atrijumi su postavljeni oko jednog velikog atrijuma i tako zajedno čine modernu vilu rustiku. Nadzemni nivo se sastoji od četiri kaskadno postavljena podnivoa, međusobno povezana tremovima. Osim njih tu su i galerijski i potkrovni prostori. Ispod centralnog dela objekta su smeštena dva podzemna nivoa.

Nadzemni prostori su projektovani za smeštaj 95 turista i arheologa, njihovo istraživanje i odmor. Veliki atrijum može ugostiti koncert ili predstavu bilo koje vrste i primiti veliki broj posetilaca. Dva podzemna nivoa su projektovana za stalne i povremene postavke izložbi kopija i originalnih rimskih predmeta $\mathrm{i}$ arhitekture, kao i za

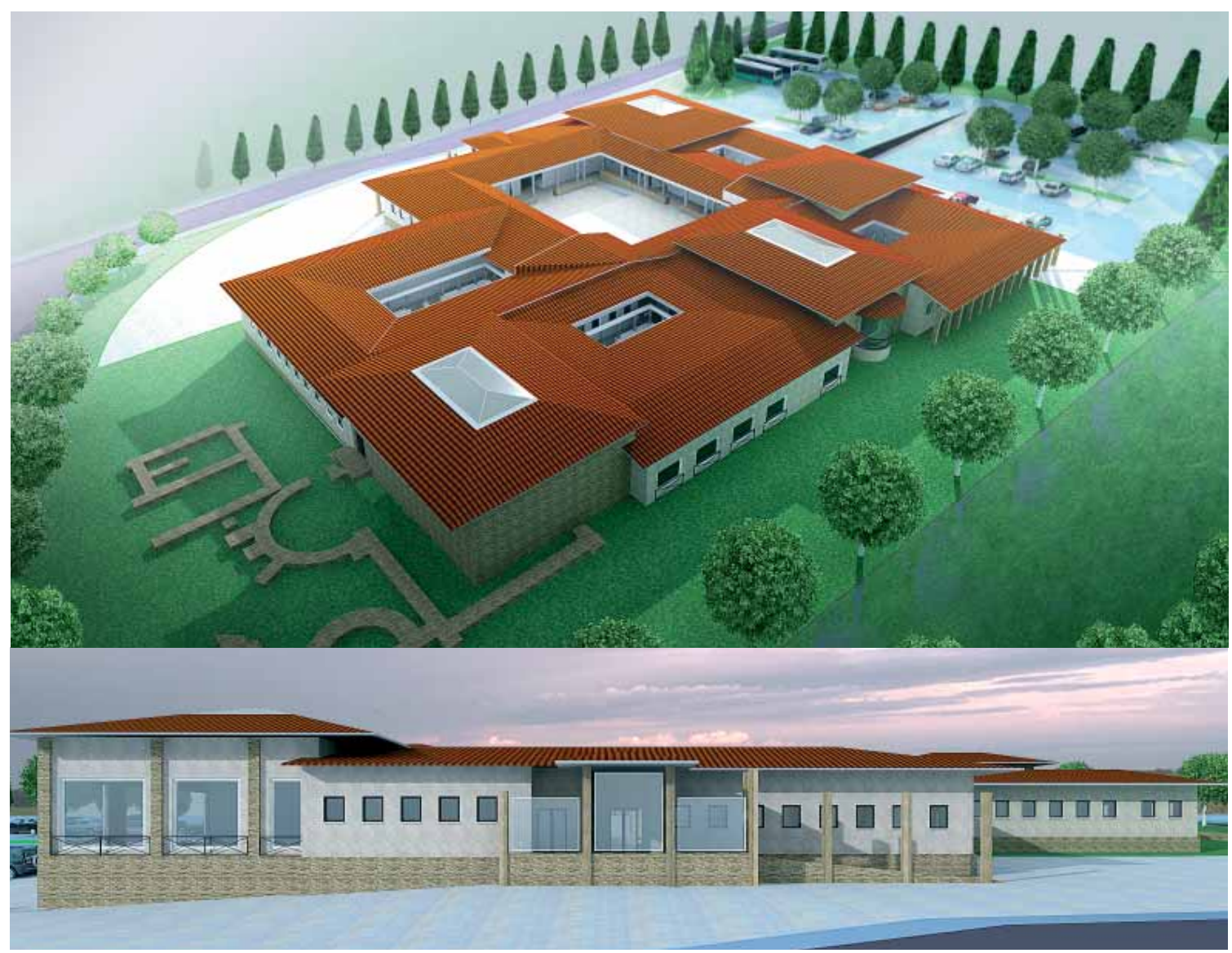

Objekat Arheološkog naučno-istraživačkog centra, prostorni modeli izgleda objekta iz vazduha i severne fasade, autor Uroš Tomašević, dipl.ing.arh. 

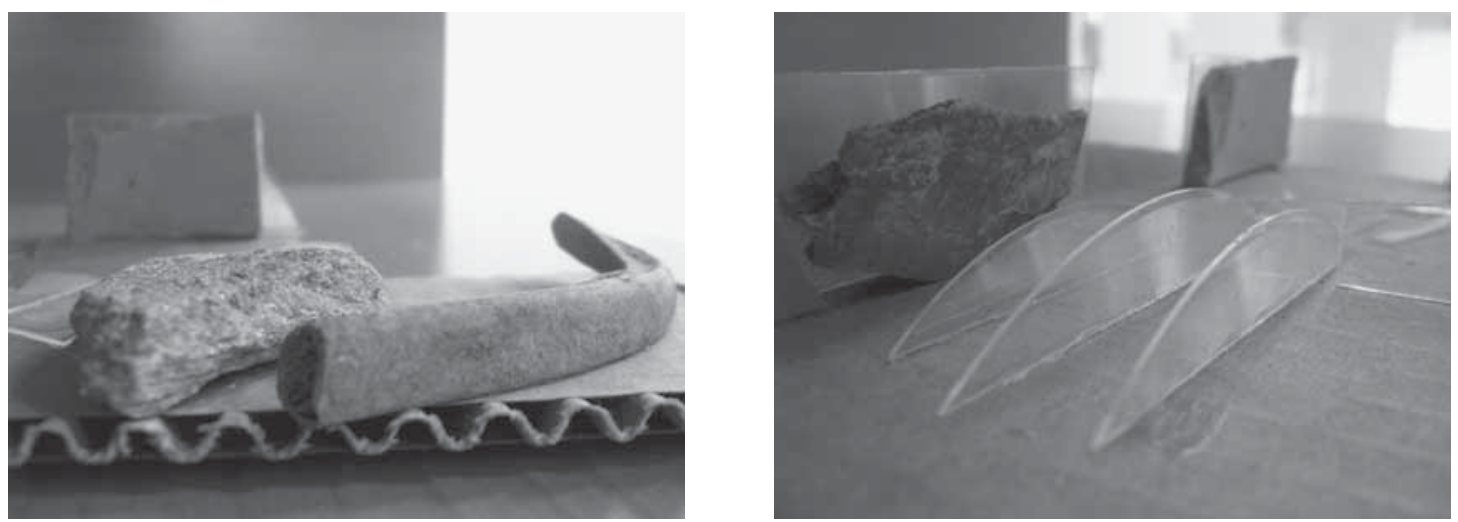

Maketa - vežba postavke antičkih i savremenih materijala (autor Emilija Nikolić, dipl.ing.arh.)

prezentacije, predstave i predavanja.

Ukupna neto površina objekta je $3,107.97 \mathrm{~m} 2$. Njegove spoljne dimenzije su $65.73 \mathrm{~m} \times 60.25 \mathrm{~m}$. Devet krila nadzemnog nivoa sa potkrovljem i galerijama su raspoređena na sledeći način:

1.administracija i smeštaj - ulaz i kancelarije sa smeštajnim jedinicama za turiste na osnovnom nivou i smeštajnim jedinicama za turiste $u$ potkrovlju,

2.smeštaj - smeštajne jedinice za studente, 3.odmor - spa centar sa bazenima
4. naučno-istraživački rad - laboratorije i radionice

5.izložbeni prostor - centralna nadzemna prostorija (veza sa podzemnim nivoima)

6.smeštaj - smeštajne jedinice za profesore

7.naučno-istraživački rad - biblioteka i čitaonica sa galerijom

8.smeštaj - smeštajne jedinice za arheologe

9.uslužno-ekonomski deo - trpezarija sa kafeom i galerijom, i kuhinja.

Dva podzemna nivoa sadrže sledeće funkcije:

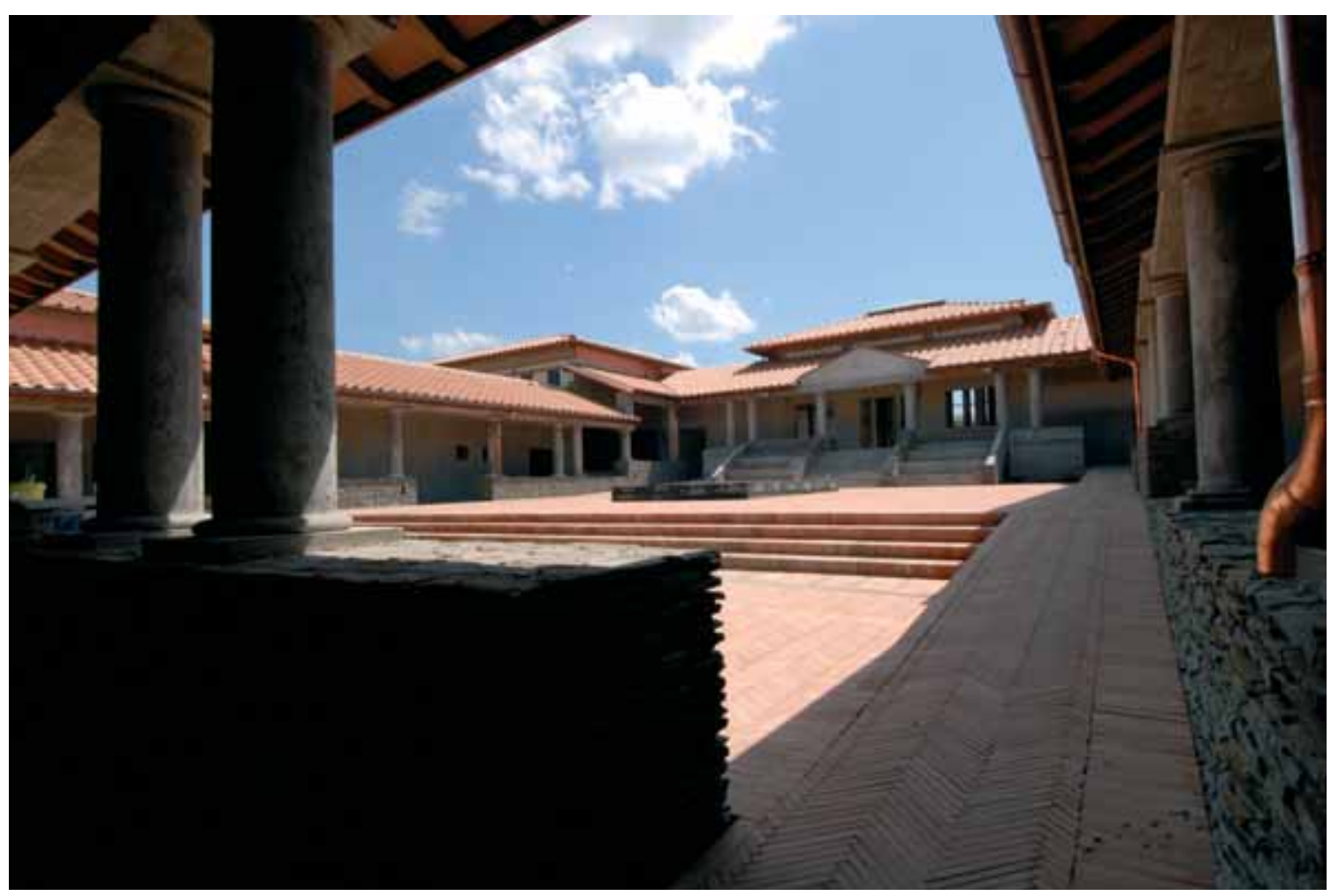

Objekat Arheološkog naučno-istraživačkog centra - centralni atrijum (snimio dr Miomir Korać) 
1.izložbeni prostor - prostor za kamene spomenike, fragmente arhitekture i skelete sa tehničkim prostorijama,

2.izložbeni prostor - prostor za keramiku, nakit, novac i sitne predmete, centralnu podzemnu prostoriju sa izloženom plastikom na zidovima i plafonom u mozaiku za konferencije, predavanja i predstave, prostor za audio-vizuelne predstave i prostor rampe sa freskama, sa tehničkim prostorijama.

\section{TEME I SIMBOLI DOMUSA}

Kako se u projektovanju modernih objekata na arheološkom nalazištu osloniti na arhitekturu iz perioda života samog nalazišta, kad ona danas ne postoji? To je pitanje koje se postavilo kao prvo pitanje prilikom projektovanja na lokalitetu. Onda su ga, posle nekog vremena, zamenila druga pitanja. Da li se uopšte treba oslanjati na bilo koju arhitekturu prošlosti dok gradimo nove objekte? Da li su dovoljne samo asocijacije i podsećanja na prošlost ili je moguće i direktno prenošenje prošlosti u sadašnjost, da bi novi objekat postojao na arheološkom nalazištu? Koja je mera te asocijacije, ili koja je mera prenošenja prošlosti?

Odgovora na bilo koje od ovih pitanja verovatno nema, jer, iako svaki period arhitekture ima svoje zajedničke principe, kanone i teorije, svaka naseobina je različita i nastala iz želja njenih stanovnika i onih koji su slučajno ili namerno došli na prazna polja i odlučili da na se na njemu nastane i izgrade sve ono što im je potrebno. Tako je i nastanak novog objekta na arheološkom nalazištu uslovljen današnjim ljudima i njihovim potrebama, za antikom ili za savremenim dobom.

Objekat arheološkog naučno-istraživačkog centra svoju funkciju duguje temama koje je nametnuo sam njegov položaj i današnji život i želje onih koji svoj rad obavljaju na Viminacijumu. Materijalizacija i oblikovanje, i sve ono što nazivamo arhitekturom u vizuelnom smislu, nastali su iz sakupljenih simbola antike i današnjeg doba, simbola koje svi razumeju i koji objektu daju smisao.

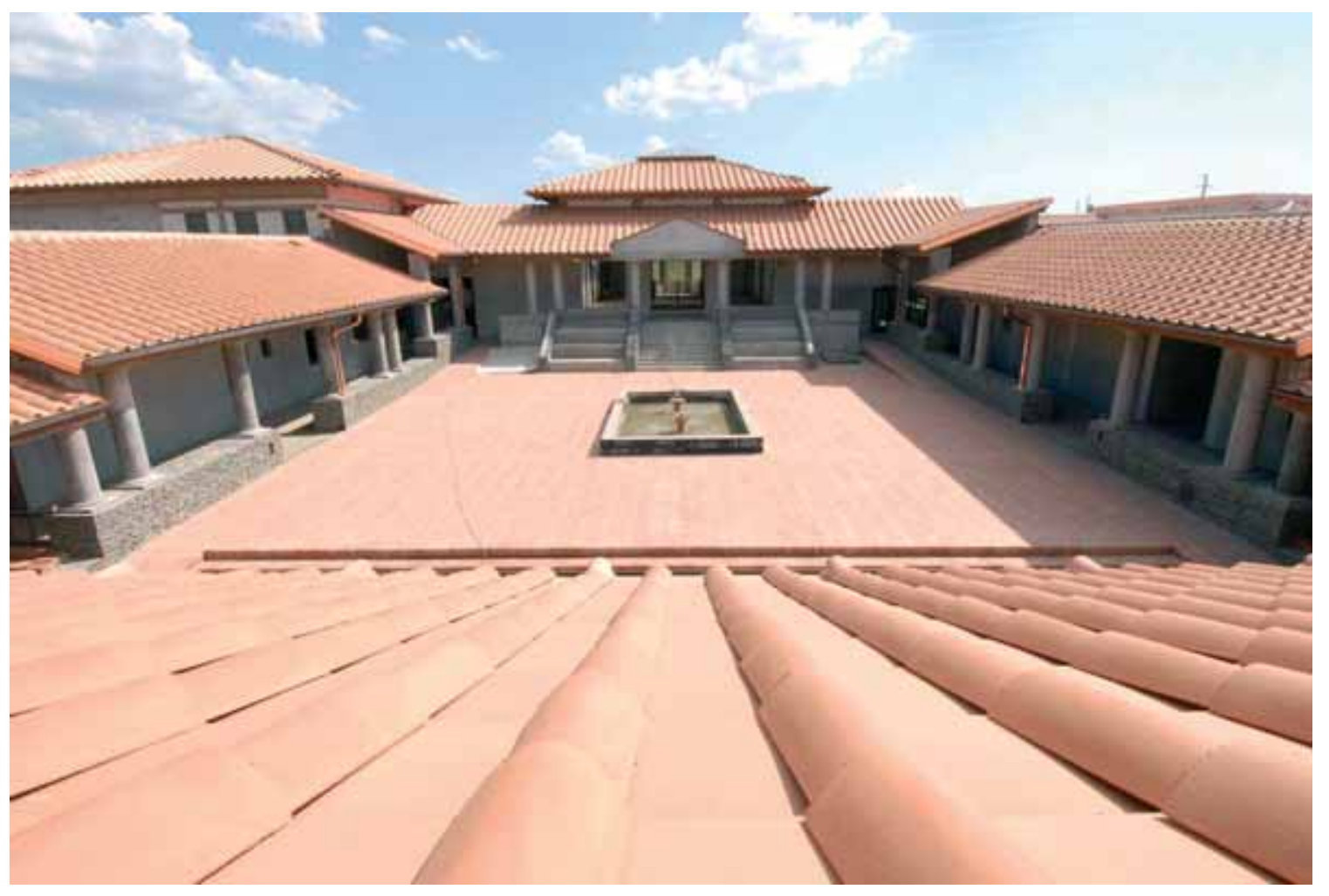

Objekat Arheološkog naučno-istraživačkog centra - centralni atrijum (snimio dr Miomir Korać) 


\section{Simboli Domusa}

\section{1. život $i$ smrt}

Domus je zamišljen kao živi objekat u "gradu mrtvih". Nadzemni delovi objekta su samo opna, živa membrana podzemnih prostora. Zemaljski život je kratak i mali u poređenju sa večnim zagrobnim životom.

\section{2. svetlost i tama}

Dodir prirodnog svetla je jedna od najvažnijih stvari kada se govori o podzemnim prostorima. On je važan za ljudsku psihologiju i ljudska osećanja. Delovi podzemnih objekata koji se ističu bi trebalo da imaju taj dodir. Ljudsko oko je onda prirodno okrenuto ka njima kao ka svetlosti u tami. Slika u niši centralne podzemne prostorije je osvetljena prirodnim svetlom koje dolazi sa padine, iz pravca "Mauzoleja", i prolazi kroz različite otvore u objektu. Svetlost, izlaz napolje, kraj tunela-rampe, kao izložbenog prostora za antičke freske, predstavlja ono čime smo privučeni, ali posle dolaska na vrh smo prisiljeni da se vratimo nazad, u "tamu". Ne možemo izaći koristeći naš prirodni put "najbliži svetlosti”, već se moramo vratiti na mesto odakle smo krenuli, i izaći istim putem kojim smo ušli.

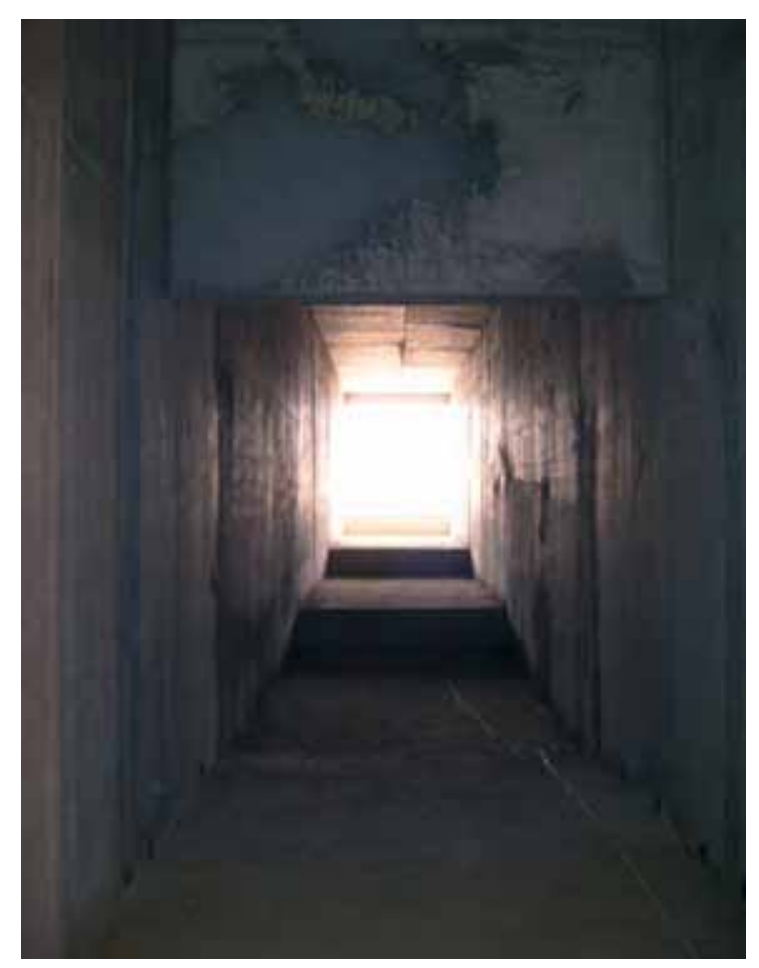

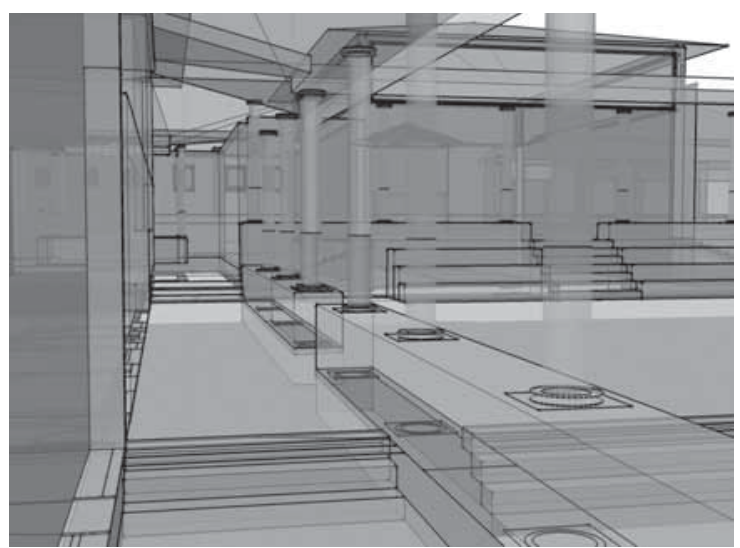

Objekat Arheološkog naučno-istraživačkog centra, prostorni model centralnog trema (autor Emilija Nikolić, dipl.ing.arh.)

\section{3. ponos i poniznost}

Gledajući kroz otvore u zidu prvog podzemnog nivoa, radoznalo pokušavamo da vidimo šta se događa ispod nas u tom trenutku, ali jedini način da to uradimo je saginjanjem, na taj način poštujući prošlost i one koji su na ovom svetu bili pre nas. U nadzemnim prostorima, uvek težimo da budemo različiti i jedinstveni u društvu. U podzemnom svetu smo svi isti. U prostor, na najnižem nivou objekta, podzemnu centralnu prostoriju, dolazimo prolazeći kroz niži hodnik, a pogled na gore sa iznenađenjem je naša prva reakcija, Ova prostorija je simbol veličine i naše impresije tom veličinom.

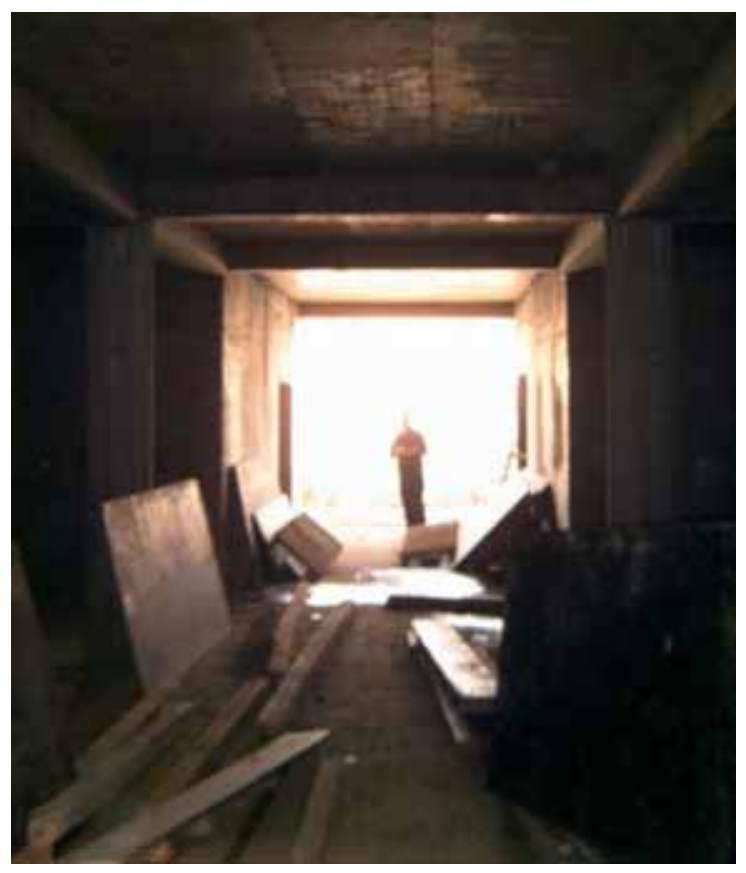

Podzemna rampa i hol - izložbeni prostor (snimila Emilija Nikolić) 

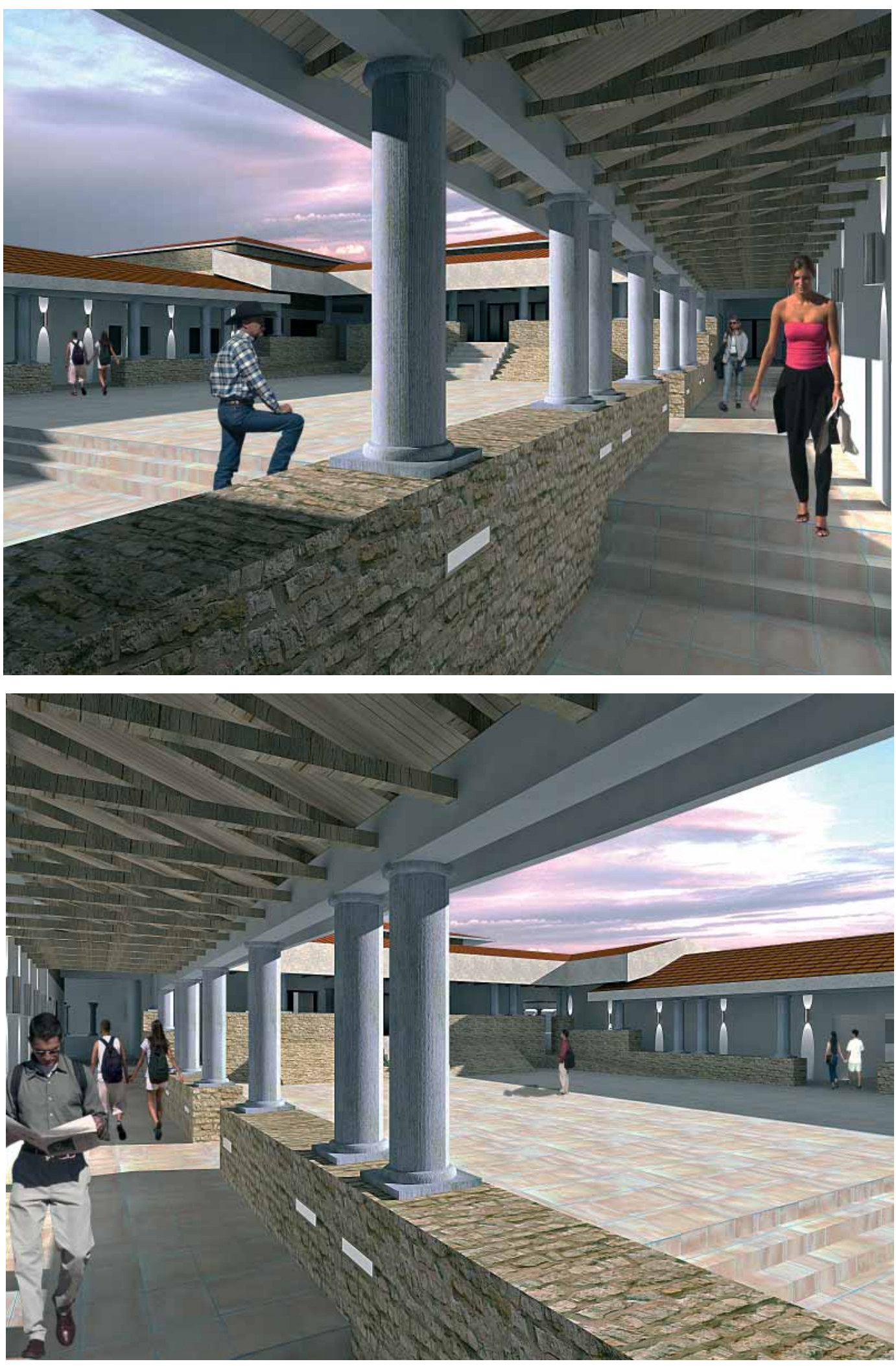

Objekat Arheološkog naučno-istraživačkog centra, prostorni model centralnog atrijuma i centralnog trema (autor Uroš Tomašević, dipl.ing.arh.) 


\section{ZAKLJUC̈AK}

Jedan od mogućih budućih poteza u povezivanju objekta sa svojom okolinom je podzemna veza Domusa i "Mauzoleja". Hodnici "Mauzoleja" sa grobnicama se mogu povezati sa izložbenim prostorima Domusa, i postati jednistvena izložba podzemnog antičkog sveta.

U proleće, Domus postaje dom za turiste koji dolaze da vide Viminacijum i njegovo okruženje, kao jedan od svojih pristana na putovanju Dunavom. Broj turista se leti povećava sa radionicama i letnjim školama. U jesen, studentske ekskurzije imaju jedan od svojih ciljnih mesta baš ovde, a ovdašnja zima je period za naučnike i poštovaoce nauke kojima treba mir i privatnost za svoj rad. Tokom cele godine, Domus je domaćin prezentacija, predavanja i mesto stalne izložbene postavke antičkog Viminacijuma.

Napor da se izgradi moderna kuća, sa modernim funkcijama, za moderan život, ali u antičkom ambijentu i sa antičkim podsećanjima, uvek praćen citatom sa početka ovog teksta, dao je rezultat u oblikovanju nadzemnog dela ovog objekta. Podzemni prostori su projektovani kao moderni i donekle kolosalni, ali samo kao domaćini izložbi antičkog zivota. Domus u sebi sadrži moderan život $u$ antičkom ambijentu i antički život $u$ modernom ambijentu, svaki na svom mestu. Bez sumnje, objekat će imati svoj sopstveni savremeni život, uvek poštujući prošlost.

\section{BIBLIOGRAFIJA}

\section{Ruskin 1849}

J.Ruskin, The Seven Lamps Of Architecture, John Wiley, 161 Broadway, New York, 1849.

\section{ARCHAEOLOGICAL SCIENTIFIC AND RESEARCH CENTRE - DOMUS SCIENTIARUM VIMINACIUM}

Viminacium is the most popular and most visited archeological site in Serbia today.

Newly built object of Archeological Scientific and Research Centre "Domus Scientiarum Viminacium" is an attempt to fulfill architectural and archeological, theoretical and practical, moral and payable... all the requirements, that are stationed in design of new buildings built on archeological sites.

Designer has many questions to ask himself in the situation. What is the right way to design and is there an universal architecture that can be followed in any time, or only the universal architectural rules exist? What is modern life in an ancient ambient, and can we put ourselves in the past time, only by being present in a past-like building? Is the association the solution, or the aspires of those who will use the building are the most important clues in finding the best design for that building?

Are there answers on any of these questions?

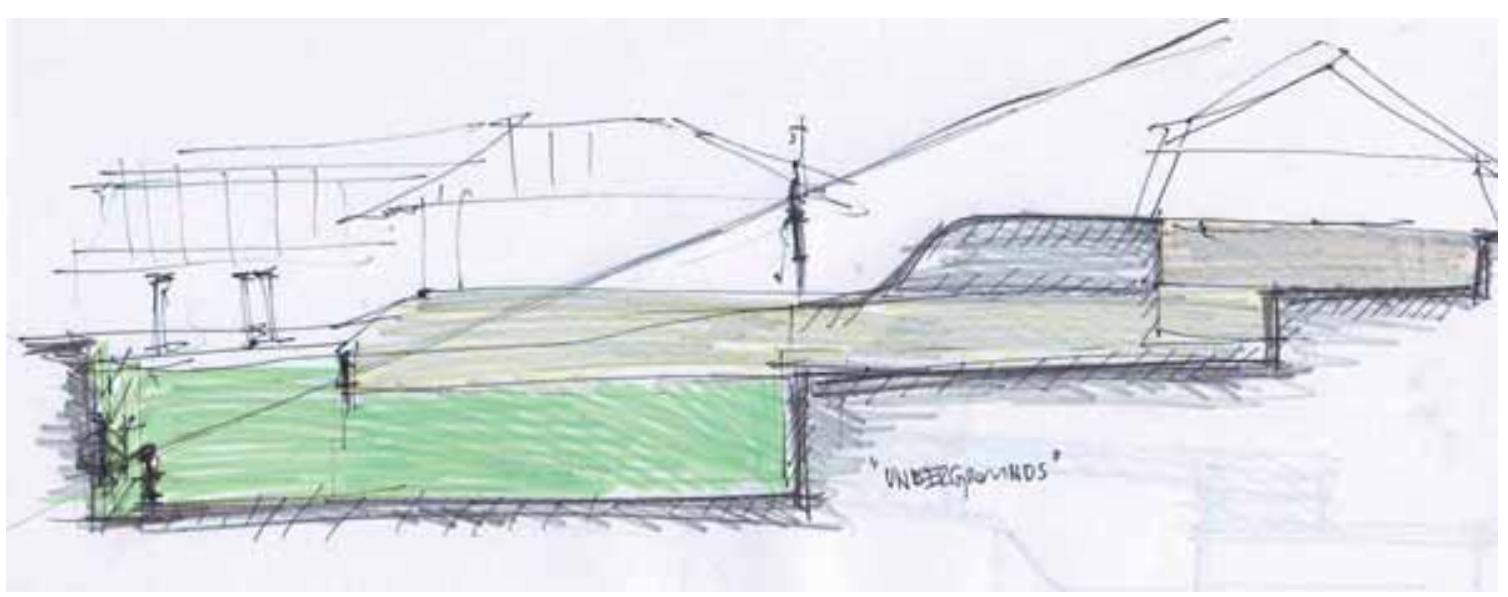

Objekat Arheološkog naučno-istraživačkog centra i „Mauzolej“, skica podzemne veze Domusa i Mauzoleja (autor Emilija Nikolić, dipl.ing.arh.) 

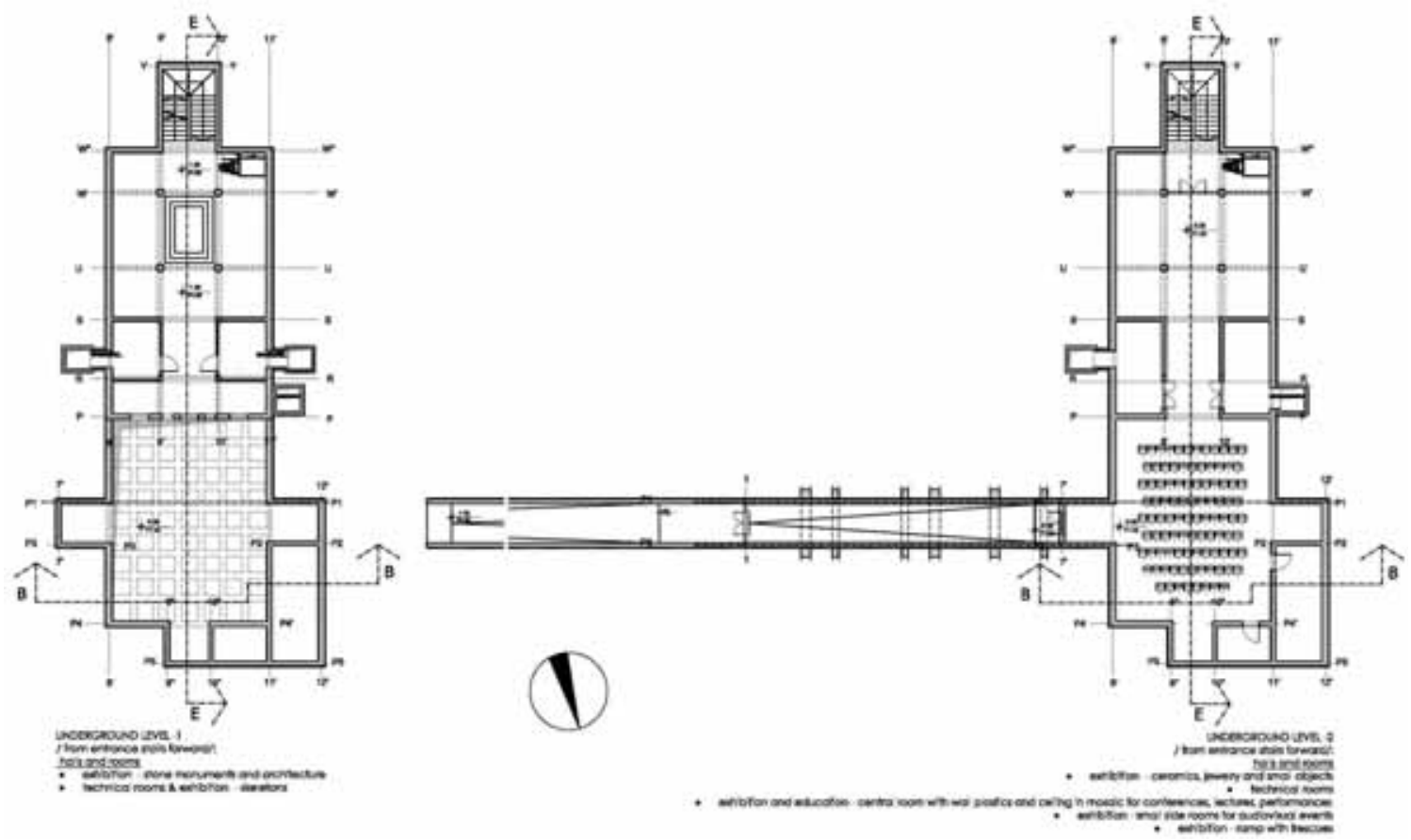

Objekat Arheološkog naučno-istraživačkog centra,

arhitektonski crteži osnova podzemnih nivoa (autor Emilija Nikolić, dipl.ing.arh.)

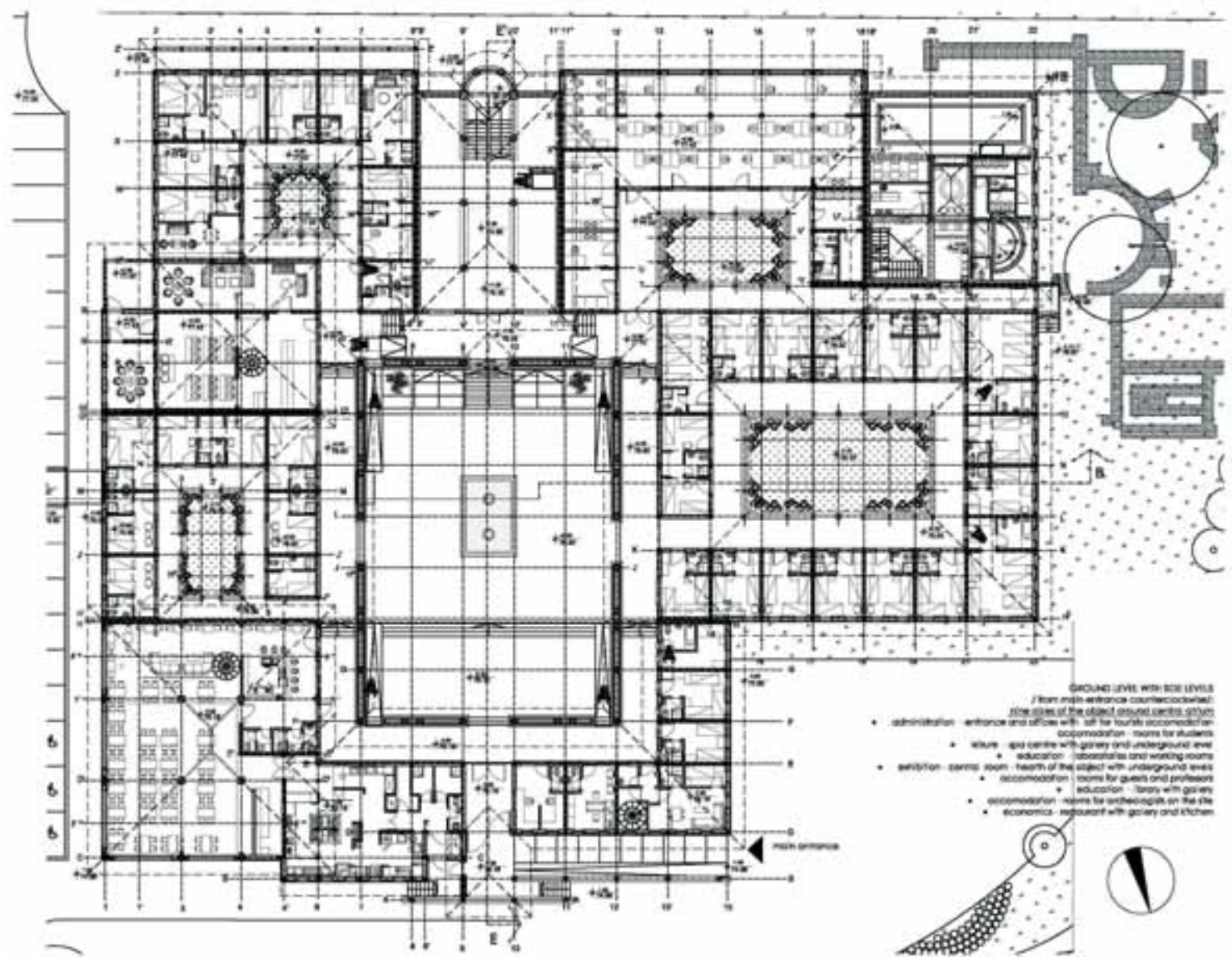

Objekat Arheološkog naučno-istraživačkog centra,

arhitektonski crtež osnove nadzemnog nivoa -prizemlja (autor Emilija Nikolić, dipl.ing.arh.) 

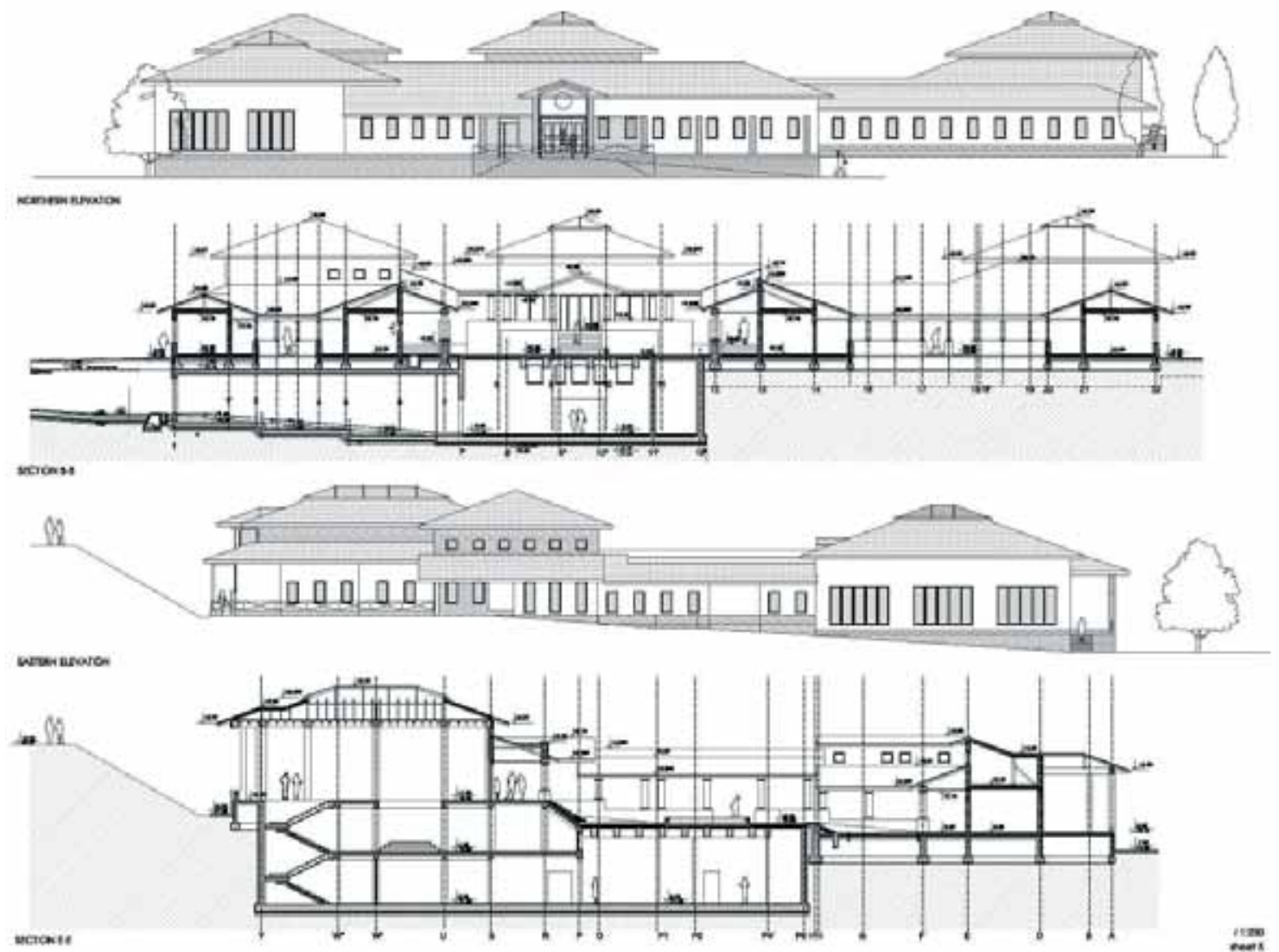

Objekat Arheološkog naučno-istraživačkog centra, arhitektonski crteži podužnog i poprečnog preseka i severne i istocne fasade (autor Emilija Nikolić, dipl.ing.arh.)

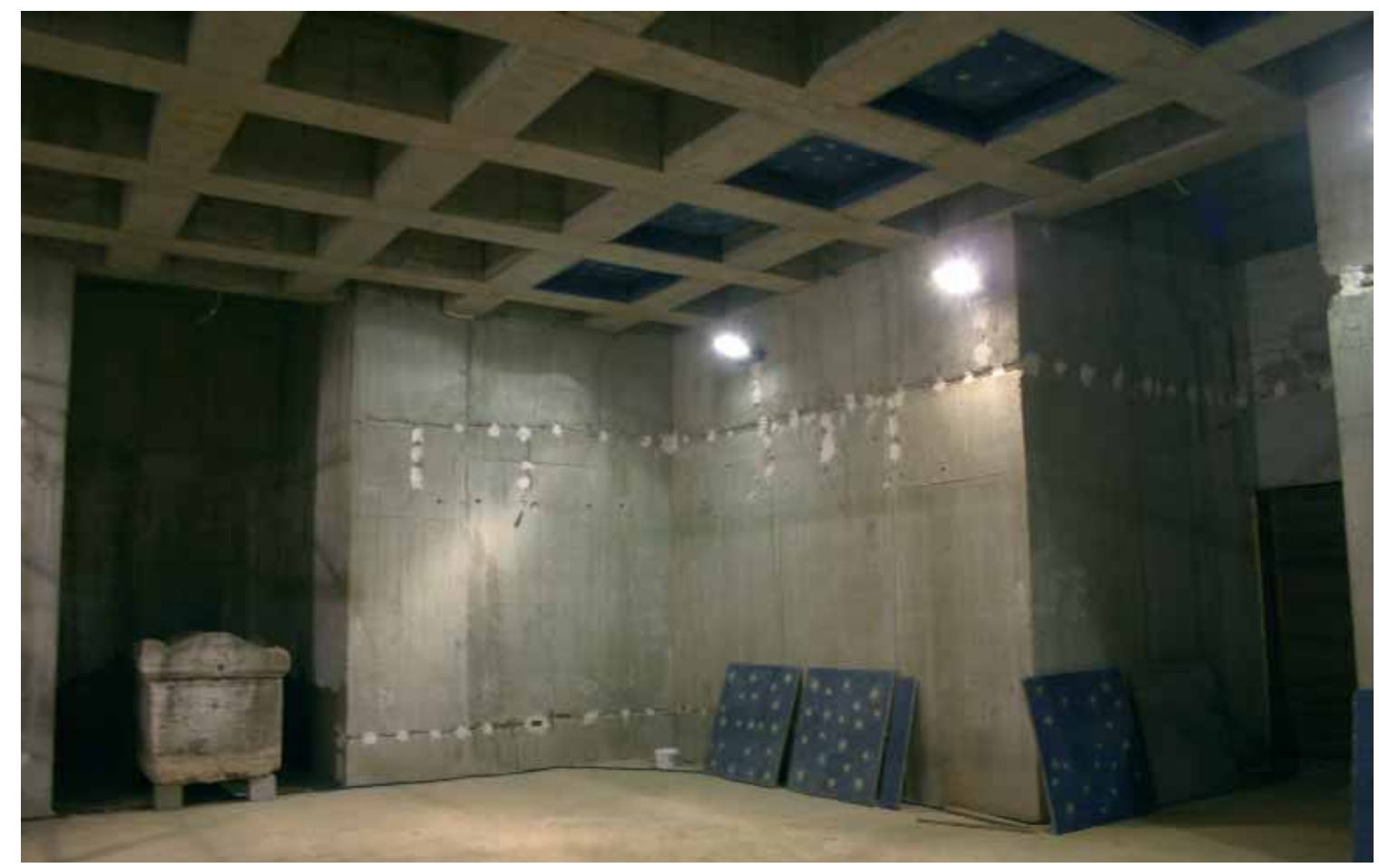

Kasetirana tavanica centralne podzemne prostorije sa mozaikom (fotografija N. Mrđić) 